\title{
Factors increase interest of undergraduates to English newspapers in Al-Beroni University of Afghanistan
}

\author{
${ }^{1}$ Ahmad Jahed Mushtaq \& ${ }^{1}$ Dr Zuraina Bt Ali \\ Centre for Modern Language and Human Science (CMLHS) \\ University Malaysia Pahang (UMP)
}

\begin{abstract}
Reading is advised as a beneficial activity for everyone. It informs readers of interested issues. Newspapers are suitable reading tools. They bring day-to-day issues. Also newspaper reading inculcates reading habits among the society. English newspapers are best reading materials for English language students. They offer numerous matters for readers in different languages. They also make better English languages ability of readers. However, English newspaper reading habits of undergraduates in Al-Beroni University of Afghanistan looks like to be fewer. Thus, the aim of this paper is to discover the factors that increase interest of students to English newspapers. This was made by using mixed methods. In qualitative method, 97 students were randomly chosen as the subjects of the study. Also ten students were interviewed. Findings show Provides interesting information, distribute for free and disclosing realities of society are factors that increase interest of students to English newspaper reading. Also there was no significant difference between male and female students in regarding to factors that increase interest in English newspaper reading.

Key words: Reading, Habits, English newspaper, Undergraduates
\end{abstract}

\section{Introduction}

Reading has taken a top position in education. It heightens awareness of students in multiple subjects, which are the student's choices i.e. politic, economy, culture and so on (Anas Alam Faizli, 2012). In addition reading keeps informed readers till they are lived (Igbokwe, Ezeeji, \& Obidike, 2012). Additionally, reading of newspaper pave the way for readers to increase their reading habits more than before (Devendra Kumar, Rajkumar Singh, and \& Jamal Ahmad Siddiqui, 2011). Beside, a person who read English newspapers improves his/her English languages skills. Akdemir and Demiroz (2012) found that the English newspapers have considerable effect on the conversation skills of students. They also alleged that English newspaper writings are one of the most suitable materials to use in communicating daily oral language, as well as it builds vocabulary store of readers. According to researchers when persons use newspaper, it enables them to get his/her reading materials directly. Besides it saves time and money of readers.

\subsection{Limitation of the study}

The findings of this investigation is limited to English department of Literature and Language Faculty of Al-Beroni University bachelor students, who read or do not read English newspapers. Therefore, it does not comprise the English newspaper reading habits of all students or youth in other universities in Afghanistan.

\section{Literature Review}

There are many studies conducted on reading habits internationally.Mostly, these studies focus on the University and school students reading habits. These studies found that the reading habits of students are very less, and day by day it has been decreasing (using \& Muursepp 2012; Igbokwe \& Ezeeji, 2012; Pehlivan, Serin \& Serin, 2010; Gorsuch \& Taguchi, 2008; Cheang Eng Kwong Hajah Hasinah Bt Othman \& Polamarasetty Deva Rajeswari, 2005), as well as newspapers reading habits have decreased across many countries for the past decades. Despite of struggles of many newspaper organizations to find the motives behind the lack of newspaper reading habit, still they have not succeeded to release exact solution of the problem (The Decode Research Consultancy, 2008).

However, one of the most excellent ways to encourage customers to read the English newspapers is by proper showing to the society and informing students about the fresh information provided on the subject of education (Devendra Kumar, Rajkumar Singh, \& Jamal Ahmad Siddiqui, 2011). Besides Akpınar (2012) stated that newspaper should give background information of reports for students to comprehend the texts. This will guide readers to continuous interests in newspaper reading. Furthermore for increasing of English newspaper reading habit among the students some studies recommended including of newspaper reading as a part of schools' subjects. This implies that newspaper reading should be integrated into the curriculum as chemistry, math, and biology subjects (Rajpar, Salim \& Hassan, 2010; Martire, 2004, Pardun \& Scott, 2004). 
Despite of the above mentioned studies about youth newspaper reading habits and their findings, Bentley (2000) conducted a study about the habits of newspaper reading in the U.S stated that one of the most important factors have a significant role in increasing newspaper readership is habit. He alleged if newspaper publishers want to be successful, they must find their habitual readers and then respect them by offering discounts and rewards. Subsequently find their interests in newspapers.

\section{Methodology}

For collecting data, a quantitative survey was used to collect related data. In order to deepen the findings semi structured interviews were conducted with the participants, as well.

\subsection{Participants}

The participants of the study were bachelor students of Al-Beroni University of Afghanistan. These participants were randomly selected from the first, second, third and fourth year's students. Ninety seven students randomly chosen as the subjects of quantitative data, later ten students were called for interviews. These participants were from all parts of country.

\subsection{Instruments and data analyse}

The interview protocol questions and questionnaires were used as the instruments of the study. Questionnaire items consists of 15 Lickert scale questions divided in three parts by this study researcher with accordance to previous researchers questionnaires items i.e. Wilson (2009) Wolswinkel (2008). In addition interview protocol questions include nine open items was conducted among the students. Moreover quantitative data were analysed in SPSS using descriptive and independent sample $t$ test, while themes were emerged from qualitative data analysis based on the research questions and responses of the interviewees.

\section{Respondents profile}

The demographic part of questionnaire consists of three items, which are gender, ages and education years of respondents. Following explains demographic information of respondents.

\subsection{Gender of respondents}

Table 4.1 depicts number of male and female students took part in the study. Of the 97 total students who participated in the study, majority $69(71.1 \%)$ were male, while $28(28.9 \%)$ were female. This indicates that the number of male students participated in the study is significant than the female. This is because in the research area of the study has been fewer female students.

Table 4.1: Gender of respondents

\begin{tabular}{|l|l|l|}
\hline & Frequency & Percent \\
\hline Male & 69 & 71.1 \\
\hline Female & 28 & 28.9 \\
\hline Total & 97 & 100.0 \\
\hline
\end{tabular}

\subsection{Ages of respondents}

Table 4.2 shows that $17(17.5 \%)$ students were aged 25 and above years, and $38(39.2 \%)$ students were aged 18-20 years. The largest groups of students $42(43.3 \%)$ comprised of those in the age groups of 21-25 years. The smallest groups of respondents $17(17.5 \%)$ were 25 and above years.

Table 4.2: Ages of respondents

\begin{tabular}{|l|l|l|}
\hline & Frequency & Percent \\
\hline $18-20$ & 38 & 39.2 \\
\hline $21-25$ & 42 & 43.3 \\
\hline 25 -above & 17 & 17.5 \\
\hline Total & 97 & 100.0 \\
\hline
\end{tabular}

\subsection{Studying year of respondents}

Table 4.3 depicts education years of respondents. As it shows among the 97 respondents $29(29.9 \%)$ were forth year students and $26(26.8 \%)$ were second year students. Twenty two $(22.7 \%)$ were third year students, and also 20 (20.6\%) were first year students. Therefore the large numbers of respondents were forth year students, while least of them were first year students. 
Table 4.3: Studying years of respondents

\begin{tabular}{|l|l|l|}
\hline & Frequency & Percent \\
\hline First year & 20 & 20.6 \\
\hline Second year & 26 & 26.8 \\
\hline Third year & 22 & 22.7 \\
\hline Forth year & 29 & 29.9 \\
\hline Total & 97 & 100.0 \\
\hline
\end{tabular}

\section{Findings}

Results and findings of the study are divided in two parts. First part presents quantitative data followed by qualitative data.

\subsection{Quantitative findings}

A total of 97 questionnaires were administered among the first, second, third and fourth year's students of English department of Language and Literature Faculty in Al-Beroni University of Afghanistan. Questionnaires consist of demographic information and English newspaper reading habits questions. In addition questionnaire has 15 Lickert Scale items. Each item for example consists of strongly agree, Agree, Undecided, Disagree and strongly disagrees. The value for strongly agree was given (5), while for strongly disagree was assigned (1), and for the rest of scales within two above scales, given values were 4, 3, and 2. Moreover in order to know the reliability of questionnaire, all questions entered in to the (SPSS) Social Science Statistical Package. The Cronbach's Alpha was .706.

\subsubsection{Factors to increase interest}

In order to evaluate the effect of gender as well as to find the differences between male and female concerning to the factors that increase interest of students to English newspapers. The following hypothesis was created:

Ho1: There is no significant difference between males and females students concerning to factors that increase interest in English newspapers.

An independent sample $t$ test was used to compare Factors increase interest of English newspaper reading habits scores between male and female. Results in the table 4.6 and 4.7 , describe that there is no significant differences in mean scores for male $(M=2.9478, S D=.65318)$ and female $(M=3.3857, S D=.81455)$; $\mathrm{t}$ (95) $-2.781, \mathrm{P}>0.05$. Since there is no significant difference between male and female in factors to increase English newspaper reading interest, therefore the null hypothesis did not reject.

Table 4.6: mean and Std. Deviation for Factors to increase interest by gender

\begin{tabular}{|l|l|l|l|l|}
\hline Gender & $\mathrm{N}$ & Mean & Std. Deviation & Std. Error Mean \\
\hline Male & 69 & 2.9478 & .65318 & .07863 \\
\hline Female & 28 & 3.3857 & .81455 & .15394 \\
\hline
\end{tabular}

Table 4.7: Independent Samples $t$ test for factors to increase interest by gender

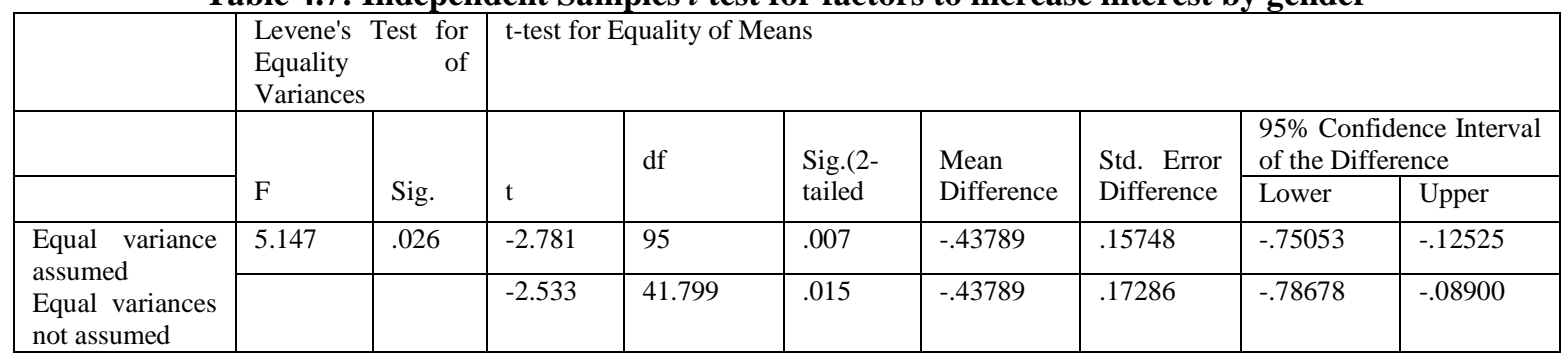

\subsection{Qualitative findings}

In collecting qualitative data ten students were interviewed; five male and five female. These participants were drawn from the first, second, third and fourth years students of English language department of Al-Beorni university. Interviews were conducted among students using semi structured interviews. Additionally for reporting students' responses in paper, students were asked to write their real name or pseudonym; all of them were agreed that their real name should be mentioned.So the real names of interviewees is mentioned. Male interviewees are: Abdul Rashid Rashed, Ahmad Faiaq, Ahmad Khaled Aryan, Nasrtullah Behroz, and Mohabat 
Habibi. Also females are: Lina, Taiaba, Mariam Moqadas, Husna and Khatera. After data was collected, it was transcribed. Themes that were related to the research question of study were highlighted. The emerged themes were identified and categorised under the main theme that is factors to increase interest. It is introduced in below.

\section{Factors to increase interest}

The themes that are related to factors to that increase interest are: 'Newspaper provides interesting information', 'Distribute for free', and 'Disclose realities of society'.

\section{a) Provide interesting information}

This theme indicates that the most of respondents would like to read newspapers that present interesting information in its pages. For example Ahmad Khaled Arian is a male student indicates when a newspaper publishes more interesting ideas and more fascinating topics that can attract attention of students, learners and other people. Similarly Khatera believes newspaper must pay attention to interesting issues. She also claimed:

As it is clear for all a newspaper must be more interesting, the titles or the headlines should be interesting and (newspaper) provide more interesting information to the readers. Overall it should be more useful and interesting, for example its headlines should be highlighted or coloured.

\section{b) Distribute for free}

In order to increase newspaper readership a number of male respondents suggested that the government should provide newspapers for free or at least with low price to students. As Ahmad Faiq said, in my point of view in order to develop culture of newspaper reading habits among the society, government must provide free newspapers for the people of society especially for students. He added, since private English language newspapers are expensive for students, free distribution of newspaper will encourage students toward reading as well as help newspaper organizations to increase their readers. Similarly Nasrtullah Behrooz recommended newspaper should be delivered to students with cheap price, he said:

In my opinion if newspapers reduce their prices, on that time the culture of newspaper readership will be developed among the society.

\section{c) Disclose realities of society}

This theme was identified for the reason that some of male and female students stated; newspapers that reveal realities of society may attract more readers. Students who suggested this theme said since all of people follow news, and they prefer those newspapers describe facts of their society. For instance a male student, Abdul Rashid Rashid said in my point of view if a newspaper discloses realities of society, it will catch the attention of readers, and its readers will be increased, because all of people go through Medias reveals facts not false. Moreover a female student, Husna had same opinion, she said it is noteworthy for a newspaper to echo realities about everything especially focus and disseminate youth's problems as well as disseminates youth's opinions in its daily issues.

\section{Discussions}

This study was designed to investigate the factors that increase interest of students in English newspapers in Al-Beroni University of Afghanistan. Qualitative data showed for catching student's attention newspapers provide interesting information, distribute for free, and also disclose realities of societies. According to the student's responses, the main factors that can increase interest of readers to English newspaper are interesting issues. For example newspapers focus on the thought-provoking topics of different themes, and highlighted its titles or headlines in order to attract attention of young readers. This finding is similar to Devendra Kumar, Rajkumar Singh, \& Jamal Ahmad Siddiqui (2011) alleged one of the most excellent ways of encouraging customers to read printed newspaper is by proper showing to the society and informing students about the fresh information provided on the subject of education.

Besides free distribution of English newspapers is another factor that can increase interest to English newspaper reading. Remarks of students show they suffer from the economic problems, and cannot buy newspapers. So they want newspapers to help them to read the medium. This is similar to Arvidson (2008) suggested in order to increase readers, free distribution of newspapers must be planned in resident places of students for example at their apartments, university and dormitory. Moreover, qualitative data found students prefer those newspapers release facts of society. They want newspapers cover and publish their problems, since students go through media activating impartially and objectively. 
Furthermore, quantitative data analysis showed there was no significant difference between male and female students regarding to factors that increase interest in English newspaper reading. Both of male and female opinions in term of factors to increase interest in English newspaper reading were same.

\section{Conclusion}

This study was designed to find the factors that increase interest of student's in English newspapers in AlBeroni of Afghanistan. The results of data showed that provide interesting information, disclose realities of society and free distribution of English newspapers among the society are factors that increase interest in English newspaper reading. Also there was no significant difference between male and female in term of factors that increase interest in English newspaper reading.

\section{Acknowledgement}

We are grateful of our Gods' helps. Gives us everything we want. Also thanks from our beloved families, especially parents, whose encouragements and supports push us forward.

\section{Reference}

[1]. Akdemir, S, K., Barin, M., \& Demiroz, H. (2012). Broadsheet English: teaching speaking through newspaper articles. Procedia Social and Behavioral Sciences 463967 - 3971

[2]. Akpınar, K, D. (2012). Developing foreign language newspaper reading habits of ELT Prospectiveteachers. Contemporary Online Language Education Journal, 2 (1), 44-72.

[3]. Arvidson,.C. (2008).Youth Media DNA; in search of lifelong readers. Newspaper Association of American Foundation.

[4]. Cheang Eng Kwong Hajah Hasinah Bt Othman \& Polamarasetty Deva Rajeswari. (2005). A Survey of the Reading Habits among UiTM Perlis Undergraduate Students. University Technology Mara. Dissertation.

[5]. Devendra Kumar, Ansari, M. M. A. \& Sanjay Kumar Shukla. (2010). Reading habits of senior secondary students at Allahabad city, U.P. India. Library Philosophy and Practice 2010. ISSN1522-0222.

[6]. Faizli, Anas, Alam. (2012). Inculcating reading toward a first world nation. The Malaysian Insider; Retrieved March4, 2013 from Malaysian insider.com.

[7]. Gorsuch, G,. \& Taguchi, E. (2008). Repeated reading for developing reading fluency and reading comprehension: The case of EFL learners in Vietnam. System (36) 253-278.

[8]. Igbokwe, J, C., Ezeeji, E, C. \& Obidike, N, A (2012). Influence of Electronic Media on Reading Ability of Schoo Children.Library Philosophy and Practice (e-journal), ISSN 1522-0222.

[9]. Martire,Clark., \& Borton. (2004). Growing livelong readers; the impact of the student Involvement with newspaper on adult readership; Newspaper Association of America Foundations. Vienna.

[10]. Pehlivan., \&Serin. (2010). Determining reading interests and habits of candidate teachers (TRNC Sample).Procedia Social and Behavioral Sciences 9 (2010) 869-873.

[11]. Pardun, C. J. \& Scott, G. W. (2004).Reading newspapers ranked lowest versus other media for early teens. Newspaper Research Journal.25 (3).

[12]. Rajpar, A, A., Salim, S, k., \& Hassan, S, J. (2010). Impact on student newspaper readership after the proliferation of TV news channels. Research paper.

[13]. The DECODE Research Consultancy. (2008). Youth Media DNA Finland; Decoding the Media and news consumption of Finnish youth 15-29.www.d-code.com.

[14]. Wolswinkel, H. (2008). Newspaper reading behavior of young adults; University of Twente; Nederland. Dissertation. 